\title{
KEWENANGAN PERAWAT DALAM MEMBERIKAN TINDAKAN INJEKSI STREPTOMISIN DI PUSKESMAS DIHUBUNGKAN DENGAN PERATURAN MENTERI KESEHATAN NOMOR 39 TAHUN 2016 TENTANG PEDOMAN PENYELENGGARAAN PROGRAM INDONESIA SEHAT DENGAN PENDEKATAN KELUARGA (STUDI KASUS TB PARU DI PUSKESMAS PASIRKALIKI KOTA BANDUNG)
}

\author{
Makmur Jaya \\ Email : makmur7aya@gmail.com
}

\begin{abstract}
ABSTRAK
Perawat pelaksana perkesmas adalah semua tenaga fungsional perawat di Puskesmas yang memberikan pelayanan asuhan keperawatan baik kepada individu, keluarga, maupun kelompok seperti termuat dalam Peraturan Menteri Kesehatan Nomor 39 Tahun 2016 Tentang Pedoman Penyelenggaraan Program Indonesia Sehat yang dilaksanakan untuk meningkatkan derajat kesehatan masyarakat, melalui upaya kesehatan dan pemberdayaan masyarakat. Berdasarkan data yang didapatkan dari Dinas Kesehatan Kota Bandung pada tahun 2017 salah satu penyakit menular yang banyak dijumpai adalah penyakit TB Paru yaitu sebanyak 9632 kasus. Penelitian ini menggunakan pendekatan yuridis normatif dengan menggunakan data sekunder yang didukung data primer teknik pengumpulan data dilakukan melalui wawancara serta studi kepustakaan. Hasil yang diperoleh dari penelitian ini adalah: Perawat dalam melakukan tindakan injeksi streptomisin di Puskesmas Pasirkaliki Kota Bandung tidak melanggar wewenang praktik keperawatan selama perawat yang memberikan tindakan injeksi streptomisin pasien TB Paru kategori 2 sesuai dengan Pasal 29 ayat (1) dan Pasal 32 ayat (1) Undang-Undang Nomor 38 Tahun 2014 Tentang Keperawatan.
\end{abstract}

Kata Kunci : Kewenangan Perawat, Tuberkulosis (TB Paru), Injeksi Streptomisin.

\begin{abstract}
Perpetual implementing nurses are all functional nurses in the Puskesmas who provide nursing care services to individuals, families, and groups as contained in the Minister of Health Regulation No. 39 of 2016 concerning Guidelines for the Implementation of the Healthy Indonesia Program implemented to improve the health status of the community, through health efforts and community empowerment. Based on data obtained from the Bandung City Health Office in 2017 one infectious disease that is often found is pulmonary $T B$ disease which is as many as 9632 cases. This study uses a normative juridical approach using secondary data supported by primary data collection techniques carried out through interviews and literature studies. The results obtained from this study are: Nurses in performing streptomycin injection at Pasirkaliki Health Center in Bandung City do not violate the authority of nursing practice for nurses who provide streptomycin injection in category 2 pulmonary TB patients according to Article 29 paragraph (1) and Article 32 paragraph (1) Law No. 38 of 2014 concerning Nursing.
\end{abstract}

Keywords: Nurse Authority, Tuberculosis (Pulmonary TB), Streptomycin Injection.

\section{A. PENDAHULUAN}




\section{Latar Belakang Penelitian}

Tujuan nasional bangsa Indonesia sesuai Pembukaan UUD 1945, yaitu melindungi segenap bangsa Indonesia dan seluruh tumpah darah Indonesia dan untuk memajukan kesejahteraan umum, mencerdaskan kehidupan bangsa, dan ikut melaksanakan ketertiban dunia yang berdasarkan kemerdekaan, perdamaian abadi dan keadilan sosial, maka pembangunan kesehatan diarahkan untuk meningkatkan kesadaran, kemauan, dan kemampuan hidup sehat bagi setiap orang agar peningkatan derajat kesehatan masyarakat yang setinggi-tingginya dapat terwujud. ${ }^{1}$

Kesehatan merupakan hak asasi manusia dan salah satu unsur kesejahteraan yang harus diwujudkan sesuai dengan cita-cita bangsa Indonesia sebagaimana dimaksud dalam Pancasila dan Pembukaan Undang-Undang Dasar Negara Republik Indonesia Tahun 1945. Oleh karena itu, setiap kegiatan dan upaya untuk meningkatkan derajat kesehatan masyarakat yang setinggi-tingginya dilaksanakan berdasarkan prinsip non diskriminatif, partisipatif, perlindungan, dan berkelanjutan yang sangat penting artinya bagi pembentukan sumber dayamanusia Indonesia, peningkatan

${ }^{1}$ Budiman, Buku Ajar Isu Tataran Kesehatan Masyarakat, Bandung: PT. Refika Aditama, 2015, HIm. 20 ketahanan dan daya saing bangsa, serta pembangunan nasional. ${ }^{2}$

Keberhasilan pembangunan kesehatan sangat ditentukan oleh penyelenggaraan yang berkesinambungan antar upaya program dan sektor. Salah satu penyelenggaraan pembangunan kesehatan dapat diwujudkan melalui penyelenggaraan pelayanan kesehatan, dimana didalamnya termasuk pelayanan keperawatan. Berdasarkan UndangUndang RI Nomor 38 Tahun 2014 tentang Keperawatan, Praktik Keperawatan adalah pelayanan yang diberikan oleh perawat dalam bentuk asuhan keperawatan. Asuhan keperawatan sebagai inti dari praktik Keperawatan adalah kegiatan interaksi perawatan dengan klien dan lingkungannya untuk mencapai pemenuhan kebutuhan dan kemandirian klien dalam merawat dirinya. $^{3}$

Kewenangan untuk melaksanakan upaya kesehatan itulah yang memerlukan peraturan hukum sebagai dasar pembenaran hukum wewenang kesehatan tersebut. Peraturan hukum tentang upaya kesehatan saja belum cukup karena upaya kesehatan penyelenggaraannya disertai

\footnotetext{
${ }^{2}$ Penjelasan atas Undang-Undang Nomor 36 Tahun 2009 tentang Kesehatan.

${ }^{3}$ Harif Fadhillah dkk, PPNI Pedoman Praktik Keperawatan Mandiri, Tim Penyusun DPP PPNI, Jakarta 2017, Hlm. 8
} 
pendukung berupa sumber daya kesehatan baik yang berupa perangkat keras maupun perangkat lunak. Bidang sumber daya kesehatan inilah yang yang dapat memasuki kegiatan pelayanan kesehatan.Untuk mencapai peningkatan pelayanan kesehatan bagi seluruh lapisan masyarakat Indonesia yang jumlah penduduknya amat besar bukan pekerjaan mudah, oleh sebab itu diperlukan juga peraturan perlindungan hukum untuk melindungi pemberi dan penerima jasa pelayanan kesehatan. ${ }^{4}$

Tugas dan kewenangan dalam menyelenggarakan praktik keperawatan, perawat bertugas sebagai pemberi asuhan keperawatan, penyuluh dan konselor bagi klien, pengelola pelayanan keperawatan, peneliti keperawatan, pelaksana tugas berdasarkan pelimpahan wewenang; dan/atau pelaksana tugas dalam keadaan keterbatasan tertentu. $^{5}$

Perawat adalah satu-satunya profesi yang selalu berada di samping pasien yang mempunyai kesempatan besar untuk melakukan advokasi kepada pasien. ${ }^{6}$ Menurut Sri Siswati, perawat dalam memberikan pelayanan keperawatan

\footnotetext{
${ }^{4}$ Hendrik, Etika dan Hukum Kesehatan, Jakarta, EGC, 2013, Hlm. 26.

${ }^{5}$ Undang-Undang Nomor 38 Tahun 2014 Tentang Keperawatan

${ }^{6}$ Etty Nurul Afidah dan Madya Sulisno, Gambaran Pelaksanaan Peran Advokat Perawat di Rumah Sakit Negeri di Kabupaten Semarang, 2013, Hlm. 1
}

senantiasa memelihara suasana lingkungan yang menghormati nilai-nilai budaya, adat istiadat dan kelangsungan hidup beragama dari klien. ${ }^{7}$

Menurut Nursalam, peran perawat di masa depan harus berkembang seiring dengan perkembangan iptek dan tuntutan kebutuhan masyarakat, sehingga perawat dituntut mampu menjawab dan mengantisipasi terhadap dampak dari perubahan. Sebagai perawat profesional, peran yang diemban adalah "Care". 8

Dasar hukum praktik keperawatan dapat dilihat dari hak dan tanggung jawab perawat dalam Undang-Undang Nomor 9 Tahun 1960 tentang Pokok-Pokok Kesehatan, Lembaran Negara Nomor 131 Pasal 10 yang menyatakan bahwa pemerintah mengatur kedudukan hukum, wewenang, dan kesanggupan hukum tenaga kesehatan (ayat 3), dan pemerintah mengawasi serta membimbing tenaga kesehatan dalam menjalankan kewajiban dengan memperhatikan norma keagamaan (ayat 4). ${ }^{9}$ Peraturan Menteri Kesehatan Nomor 1239 Tahun 2001 tentang Registrasi dan Praktik Perawat mengatur tentang mekanisme perawat sejak lulus pendidikan

\footnotetext{
${ }^{7}$ Sri Siswati, Etika \& Hukum Kesehatan Dalam Perspektif Undang-Undang Kesehatan, Jakarta: PT. RajaGrafindo Persada, 2015, Hlm. 195.

${ }^{8}$ Nursalam, Managemen Keperawatan Aplikasi dalam Praktik Keperawatan Profesional, Jakarta : Salemba Medika, 2016, Hlm. 37

${ }^{9}$ Ta'adi, Hukum Kesehatan, Sanksi \& Motivasi bagi Perawat, Jakarta : EGC, 2012, Hlm. 19
} 
hingga mendapat Surat Izin Praktik Perawat (SIPP) sehingga seorang perawat dapat melakukan tindakan injeksi dengan pelimpahan wewenang berupa delegasi dan mandat.

Peraturan perundangan yang terkait dengan Praktik Asuhan Keperawatan :

1. Peraturan Menteri Kesehatan RI Nomor

HK.02.02/MENKES/148/I/2010 tentang Ijin dan Penyeleggaraan Praktik Perawat.

2. Peraturan Menteri Kesehatan RI Nomor 161/MENKES/PER/I/2010; tentang Registrasi Tenaga Kesehatan.

3. Peraturan Menteri Kesehatan RI Nomor

1796/MENKES/PER/VIII/2011; tentang Registrasi Tenaga Kesehatan.

4. Surat Keputusan Direktur Jenderal Pelayanan Medik Nomor: YM.00.03.2.6.7637 tentang Berlakunya Standar Asuhan Keperawatan di Rumah Sakit. $^{10}$

Perawat dalam menjalankan tugasnya dalam menerima wewenang sebagaimana yang dimaksud dalam UndangUndang Keperawatan hanya dapat diberikan secara tertulis oleh tenaga medis kepada perawat untuk melakukan sesuatu tindakan

\footnotetext{
${ }^{10}$ Ibid, Hlm. 65
}

medis dan melakukan evaluasi pelaksanaannya.Wewenang yang diberikan terbagi menjadi dua yakni tugas yang diberikan secara delegasi dan atau yang diberikan secara mandat. Pasal 32 ayat (3) Pelimpahan wewenang secara delegatif untuk melakukan sesuatu tindakan medis diberikan oleh tenaga medis (dokter) kepada perawat dengan disertai pelimpahan tanggung jawab. Tindakan hanya dapat diberikan pada perawat profesi/vokasi terlatih sesuai kompetensi yang dibutuhkan.Ini berarti tanggung jawab ada pada perawat yang melakukan tindakan medis. Dalam penjelasan UU No. 38 Tahun 2014 Pasal 32 Ayat (4) dijelaskan bahwa tindakan medis yang dapat dilimpahkan secara delegatif, antara lain menyuntik, memasang infus, dan memberikan imunisasi dasar sesuai dengan program pemerintah. Pasal 32 ayat (5) pelimpahan wewenang secara mandat diberikan oleh tenaga medis (dokter) kepada perawat untuk melakukan sesuatu tindakan medis dibawah pengawasan, tanggung jawab berada pada pemberi mandat. Tindakan medis yang dapat dilimpahkan secara mandat, antara lain adalah pemberian terapi parenteral dan penjahitan luka. ${ }^{11}$

Pelaksanaan dan pengendalian merupakan rangkaian penyelenggaraan, pemantauan, serta penilaian terhadap upaya

\footnotetext{
${ }^{11}$ Undang-Undang Nomor 38 Tahun 2014 Tentang Keperawatan
} 
perkesmas, langkah pelaksanaan dan pengendalian tersebut meliputi antara lain $:^{12}$ a .Pengorganisasian,b.Pelaksanaan kegiatan dan c. Pemantauan hasil kegiatan. Kepala puskesmas merupakan penanggung jawab kegiatan perkesmas di puskesmas, agar pelaksanaan perkesmas dapat diselenggarakan secara optimal, maka diharapkan disetiap puskesmas ditetapkan adanya perawat pelaksana, perawat penanggung jawab, dan perawat koordinator yang ada di puskesmas. ${ }^{13}$

Perawat pelaksana perkesmas adalah semua tenaga fungsional perawat di puskesmas, perawat pelaksana perkesmas memberikan pelayanan/asuhan keperawatan baik kepada individu, keluarga, maupun kelompok.Penilaian kinerja perawat pelaksana minimal menggunakan instrumen penilaian jabatan fungsional bagi perawat puskesmas.Perawat koordinator perkesmas di puskesmas bertanggung jawab kepada kepala puskesmas terhadap keberhasilan upaya perkesmas di puskesmas, mulai dari perencanaan, pelaksanaan, pemantauan serta penilaian.Koordinator perkesmas ditetapkan oleh kepala puskesmas berdasarkan kualifikasi tertentu. ${ }^{14}$

Program Indonesia Sehat dilaksanakan untuk meningkatkan derajat

\footnotetext{
${ }^{12}$ Lihat kepmenkes RI No. 279/MENKES/SK

IV/2006 Tentang Pedoman Penyelanggaraan

Kesehatan Masyarakat di Puskesmas.

${ }^{13}$ Ibid

${ }^{14}$ Ibid, HIm.22
}

kesehatan masyarakat melalui upaya kesehatan dan pemberdayaan masyarakat yang didukung dengan perlindungan finansial dan pemerataan pelayanan kesehatan. Pelaksanaan Program Indonesia Sehat diselenggarakan melalui pendekatan keluarga, yang mengintegrasikan upaya kesehatan perorangan (UKP) dan upaya kesehatan masyarakat (UKM) secara berkesinambungan, dengan target keluarga, berdasarkan data dan informasi dari Profil Kesehatan Keluarga. Pendekatan keluarga adalah salah satu cara Puskesmas untuk meningkatkan jangkauan sasaran dan mendekatkan/meningkatkan akses pelayanan kesehatan di wilayah kerjanya dengan mendatangi keluarga. Puskesmas tidak hanya menyelenggarakan paelayanan kesehatan di dalam gedung, melainkan juga keluar gedung dengan pendekatan keluarga dalam upaya menyelesaikan permasalahan kesehatan di wilayah kerjanya. ${ }^{15}$ Perkesmas merupakan bagian integral pelayanan kesehatan dasar di Puskesmas yang bertujuan untuk meningkatkan kemandirian masyarakat mengatasi masalah kesehatan yang dihadapi, sehingga tercapai derajat kesehatan optimal. Kebijakan Depkes RI Tahun 2006 dalam rangka mengupayakan terbinanya kesehatan masyarakat, diharapkan 40\% keluarga rawan kesehatan memperoleh

\footnotetext{
${ }^{15}$ Modul Pelatihan Keluarga Sehat, Pusat Pelatihan SDM Kesehatan Badan PPSDM Kesehatan Kementerian Kesehatan Tahun 2017
} 
kunjungan rumah dan pembinaan oleh tenaga kesehatan melalui kegiatan Perkesmas. ${ }^{16}$

Tuberkulosis (TB) adalah penyakit infeksi yang menular, disebabkan oleh kuman Mycobacterium tuberculosis. Penularan melalui udara, sumber penularan adalah pasien TB yang dahaknya mengandung kuman TB.Gejala umum TB pada orang dewasa adalah batuk berdahak selama 2 minggu atau lebih. Bila tidak diobati maka setelah lima tahun sebagian besar $(50 \%)$ pasien akan meninggal. ${ }^{17}$

$$
\text { Berdasarkan data Organisasi }
$$

Kesehatan Dunia (WHO), pada tahun 2015, di Indonesia korban meninggal akibat TB Paru sebanyak 100.000 kematian setiap tahunnya. Berdasarkan data BPS Tahun 2015, di Jawa Barat terdapat 59.000 orang dengan TB di Jawa Barat.Sebanyak 8.000 kasus di temukan di Kabupaten Bogor, dan di temukan 7.400 kasus di Kota Bandung.Temuan kasus TB sudah ada di 30 kecamatan, di Kota Bandung. ${ }^{18}$ Berdasarkan data dari Dinas Kesehatan Kota Bandung Penderita TB di Kota Bandung pada tahun 2017 sejumlah 9632 kasus. ${ }^{19}$ Pada tahun 2016 penderita TB Paru di Puskesmas Pasir Kaliki sejumlah: 148 orang dan tahun 2017

\footnotetext{
${ }^{16}$ Amperaningsih, Jurnal Kesehatan Kinerja Perawat Dalam Pelaksanaan Perkesmas, Bandar Lampung, 2012, Hlm. 2015

${ }^{17}$ Ibid, Hlm, 83S

${ }^{18}$ http://www.pikiran-rakyat.com/bandungraya/2017/10/16/diskriminasi-penderita-tb-masihterjadi-411653

${ }^{19}$ Dinas Kesehatan Kota Bandung Tahun 2017
}

sejumlah 106 orang. Target Program Nasional Penanggulangan TB sesuai dengan target eliminasi global adalah Eliminasi TB pada tahun 2035 dan Indonesia bebas TB tahun 2050.Eliminasi TB adalah tercapainya cakupan kasus TB 1 per 1 juta penduduk. ${ }^{20}$

$$
\text { Jumlah Tabel } 1 \text { : Case Fatality Rate }
$$
$(C F R)$ di Puskesmas Pasirkaliki Kota Bandung Provinsi Jawa Barat

\begin{tabular}{|c|l|c|c|c|c|c|}
\hline \multirow{2}{*}{ N0 } & \multirow{2}{*}{ Penyakit } & \multicolumn{3}{|c|}{ Jumlah Kasus Penyakit } & \multicolumn{2}{c|}{ Kasus Kematian } \\
\cline { 3 - 7 } & & Baru & Lama & Total & Jumlah & CFR \\
\hline 1 & Stroke & 2 & 43 & 45 & 3 & 6,67 \\
\hline 2 & Diabet & 12 & 348 & 360 & 2 & 0,56 \\
\hline 3 & Asma & 7 & 72 & 79 & 1 & 1,27 \\
\hline 4 & Lain - lain & 7 & 164 & 171 & 3 & 1,75 \\
\hline 5 & Eklamsia & 1 & 0 & 1 & 1 & 100,00 \\
\hline 6 & Jantung & 14 & 192 & 206 & 5 & 2,43 \\
\hline 7 & Hipertensi & 42 & 1188 & 1230 & 3 & 0,24 \\
\hline 8 & TBC & 13 & 324 & 337 & 1 & 0,30 \\
\hline
\end{tabular}

Sumber :Puskesmas Pasirkaliki Kota Bandung $^{21}$

Mengutip pernyataan yang

disampaikan seorang perawat sebagai kepala program ruangan TB Paru Puskesmas Pasirkaliki Kota Bandung yang menjelaskan tentang penatalaksanaan injeksi streptomisin pada pasienTB Paruyang dilakukan perawat, ini merupakan kewenangan medis maka tindakannya membutuhkan pelimpahan wewenang dari dokter kepada perawat yang pada kenyataannya selama ini perawat yang melakukan suntikan streptomisin tidak mendapatkan pelimpahan wewenang dari dokter secara tertulis dan termasuk belum

\footnotetext{
${ }^{20}$ Ibid, Hlm 83

${ }^{21}$ Puskesmas Pasirkaliki Tahun 2108
} 
adanya SOP alur pelimpahan wewenang tersebut.Streptomisin merupakan antibiotik yang menghambat pertumbuhan bakteri gram positif dan bakteri gram negatif. Streptomisin terbagi atas dua jenis, yaitu Streptomisin A dan Streptomisin B Streptomisin yang digunakan untuk pengobatan adalah Streptomisin A. Penggunaan antibiotik ini dilakukan melalui sistem injeksi. Streptomisin memiliki tingkat toksisitas yang rendah dan dapat digunakan untuk mengatasi infeksi yang resisten terhadap penisilin Akumulasi streptomisin dalam tubuh manusia dapat menyebabkan serangkaian reaksi alergi seperti bercakbercak merah pada kulit. ${ }^{22}$

Perawat yangbertugas di puskesmas yang mempunyai tenaga kompeten hanya dapat melakukan tindakan medis/pengobatan atas persetujuan dokter penanggung jawab. Namun, perawatseringkali tidak menunggu adanya pelimpahan wewenang (perintah) dari dokter untuk melakukan pelayanan medis di puskesmas, tetapi dilakukan berdasarkan pertimbangan pribadi, kelaziman, nilai kemanusian, dan kompetensinya. Pelayanan kesehatan berupa tindakan medis seharusnya memerlukan pelimpahan dari dokter. Pendelegasian wewenang/pemberian tugas

22 Riky, Proses Pemurnian Streptomisin Dari Produk Fermentasi. Institut Teknologi Bandung,2015 limpah bagi perawat di puskesmas berbeda dengan di rumah sakit, karena puskesmas dua unit upaya pelayanan, yaitu upaya kesehatan perorangan (UKP) dan upaya kesehatan Masyarakat (UKM). Pasal 37 Upaya Kesehatan Perorangan (UKP) Tingkat pertama sebagaimana dimaksud dalam Pasal 35 dilaksanakan dalam bentuk : a. Rawat Jalan b. pelayanan gawat darurat, c. pelayanan satu hari (One Day Care), d. Home care e. rawat inap berdasarkan pertimbangan kebutuhan pelayanan kesehatan. Upaya Kesehatan Perorangan (UKP) tingkat pertama sebagaimana dimaksud pada ayat (1) dilaksanakan sesuai dengan Standar Prosedur Operasional (SPO) dan Standar Pelayanan (SP). ${ }^{23}$

Dalam Permenkes RI No.67 Tahun 2016 Tentang Penanggulangan Tuberkulosis Pasal 17 ayat (3) dijelaskan bahwa Puskesmas harus menetapkan dokter, perawat, dan analis laboratorium terlatih yang bertanggung jawab terhadap pelaksanaan program Penanggulangan TB. ${ }^{24}$ Pendelegasian wewenang/tugas limpah bagi perawat di puskesmas terjadi melalui:

a. Pendelegasian wewenang upaya kesehatan perorangan (UKP) diberikan oleh dokter sebagai tenaga medis;

b. Pendelegasian wewenang upaya kesehatan masyarakat (UKM)

\footnotetext{
${ }^{23}$ Permenkes RI Nomor 75 Tahun 2014 Tentang Pusat Kesehatan Masyarakat (PUSKESMAS)

${ }^{24}$ Permenkes RI No.67 Tahun 2016 Tentang Penanggulangan Tuberkulosis
} 
diberikan oleh kepala puskesmas sebagai penanggung jawab institusi puskesmas berdasarkan Surat Keputusan Kepala Dinas Kesehatan/bupati/walikota. ${ }^{25}$

Dasar hukum pelimpahan kewenangan /tugas dokter kepada perawat terdapat dalam Pasal 29 ayat (1) huruf e, dan Pasal 32 ayat (1), ayat (2), ayat (3), ayat (4), ayat (5), ayat(6), ayat (7) Undang-Undang Nomor 38 Tahun 2014 Tentang Keperawatan.

Berdasarkan latar belakang dari uraian tersebut diatas, maka penulis tertarik untuk melakukan penelitian dengan judul "Kewenangan Perawat Memberikan Tindakan Injeksi Streptomisin Di Puskesmas Dihubungkan Dengan Peraturan Menteri Kesehatan Nomor 39 Tahun 2016 Tentang Pedoman Penyelenggaraan Program Indonesia Sehat Dengan Pendekatan Keluarga”.

\section{Identifikasi Masalah}

Bagaimana pengaturan kewenangan perawat yang memberikan tindakan injeksi streptomisin pasien TBParu menurut Undang-Undang Nomor 38 Tahun 2014 Tentang Keperawatan?

1. Bagaimana implementasi kewenangan perawat dalam memberikan tindakaninjeksi streptimisin pasien TB
Paru Puskemas Pasirkalikimenurut Undang-Undang Nomor 38 Tahun 2014 Tentang Keperawatan Dihubungkan Dengan Peraturan Menteri Kesehatan Nomor 39 Tahun 2016 Tentang Pedoman Penyelenggaraan Program Indonesia Sehat Dengan Pendekatan Keluarga?

\section{Tujuan Penelitian}

Berdasarkan identifikasi masalah, maka tujuan dari penelitian ini adalah sebagai berikut :

1. Untuk memahami pengaturan kewenangan perawat yang memberikan tindakan injeksi streptomisinpada pasien TB Paru menurut Undang-Undang Nomor 38 Tahun 2014 Tentang Keperawatan.

2. Untuk memahami implementasi kewenangan perawat dalam memberikan tindakan injeksi streptomisinpada pasien TB Paru di wilayah kerja puskesmas Pasir Kaliki menurut Undang-Undang Nomor 38 Tahun 2014 Tentang Keperawatan Dihubungkan Dengan Peraturan Menteri Kesehatan Nomor 39 Tahun 2016 Tentang Pedoman Penyelenggaraan Program Indonesia Sehat Dengan Pendekatan Keluarga.

\footnotetext{
${ }^{25}$ https://shantidk.wordpress.com/2013/08/29/peli mpahan-wewenang-dalam-rancangan-undangundang-tentang-keperawatan/
} 


\section{A. PEMBAHASAN}

A. Pengaturan Kewenangan Perawat Dalam Memberikan Tindakan Injeksi Streptomisin Pasien TB Paru Menurut Undang-Undang Nomor 38

\section{Tahun 2014 Tentang Keperawatan}

Kewajiban perawat dalam praktik merupakan suatu perbuatan dalam menjalankan tugas praktik dan harus dipenuhi perawat. Dalam Undang-Undang Kesehatan Nomor 36 Tahun 2009 Pasal 23 ayat (1) dinyatakan tenaga kesehatan berwenang untuk menyelenggarakan pelayanan kesehatan. Ayat kewenangan untuk menyelenggarakan pelayanan kesehatan tersebut dilakukan sesuai dengan bidang keahlian yang dimiliki.Ayat (3) dalam

menyelanggarakan pelayanan kesehatan, tenaga kesehatan wajib memiliki izin dari pemerintah. Ayat (4) selama memberikan Pelayanan kesehatan sebagaimana dimaksud pada ayat (1) dilarang mengutamakan kepentingan yang bernilai materi. Ayat (5) ketentuan mengenai perizinan sebagaimana dimaksud pada ayat (3) diatur dalam Peraturan Menteri (Permenkes). ${ }^{26}$

\footnotetext{
${ }^{26}$ Lihat Undang-Undang Republik Indonesia Nomor 36 Tahun 2009
}

Permenkes Nomor 17 Tahun 2013 Tentang Perubahan atas Permenkes No.HK.02.02/MENKES/148/I/2010 Tentang Izin dan Penyelenggaraan Praktik Perawat Pasal (1) Perawat adalah sesorang yang telah lulus pendidikan perawat baik didalam maupun diluar negeri sesuai dengan peraturan perundang-undangan, ayat (2) fasilitas pelayanan kesehatan adalah tempat yang digunakan untuk menyelenggarakan upaya kesehatan promotif, preventif, kuratif dan rehabilitatif. Ayat (3) Surat Izin Praktik Perawat yang selanjutnya disingkat SIPP adalah bukti tertulis yang diberikan kepada perawat untuk melakukan praktik keperawatan secara perorangan dan/atau berkelompok. Ayat (4) Standar adalah pedoman yang harus dipergunakan sebagai petunjuk dalam menjalankan profesi yang meliputi standar pelayanan, standar profesi, dan standar prosedur operasional. Ayat (5) Surat Tanda Registrasi yang selanjutnya disingkat STR adalah bukti tertulis yang diberikan oleh pemerintah kepada tenaga kesehatan yang telah memiliki sertifikat kompetensi sesuai ketentuan peraturan perundangundangan. Ayat (6) Obat bebas adalah obat yang berlogo bulatan berwarna hijau yang dapat diperoleh tanpa resep dokter. 
Ayat (7) Obat bebas terbatas adalah obat yang berlogo bulatan berwarna biru yang dapat diperoleh tanpa resep dokter. Pasal 3 ayat (2) setiap perawat yang menjalankan praktik wajib memiliki SIPP (Surat Izin Praktik Perawat) selanjutnya penyelanggaraan praktik perawat dinyatakan Pasal 8 Ayat (1) praktik keperawatan dilaksanakan pada fasilitas pelayanan kesehatan tingkat pertama, tingkat kedua, dan tingkat ketiga. Ayat (2) praktik keperawatan ditujukan kepada individu, keluarga, kelompok, dan masyarakat. Ayat (3) praktik keperawatan dilaksanakan melalui kegiatan,

a. Pelaksanaan asuhan keperawatan

b. Pelaksanaan upaya promotif, preventif, pemulihan dan pemberdayaan masyarakat, dan

c. Pelaksanaan tindakan keperawatan komplementer.

Pasal 4 asuhan keperawatan meliputi pengkajian, penetapan diagnosa keperawatan, perencanaan, implementasi dan evaluasi keperawatan.Pasal implementasi keperawatan meliputi penerapan perencanaan dan pelaksanaan tindakan keperawatan. Pasal 8 ayat (7) perawat dalam menjalankan asuhan keperawatan dapat memberikan obat bebas dan/ atau obat bebas terbatas. Pasal 10 ayat (3) dalam melaksanakan pelayanan kesehatan, perawat harus mempertimbangkan kompetensi, tingkat kedaruratan dan kemungkinan untuk dirujuk. Pasal 10 ayat (1) dalam keadaan darurat untuk penyelamatan nyawa seseorang/pasien dan tidak ada dokter ditempat kejadian, perawat dapat melakukan pelayanan kesehatan diluar kewenangan, ayat (2) perawat yang menjalankan praktik didaerah yang tidak memiliki dokter dalam rangka melaksanakan tugas pemerintah. Ayat (3) perawat dalam melaksanakan pelayanan kesehatan harus mempertimbangkan kompetensi, tingkat kedaruratan dan kemungkinan untuk dirujuk, ayat (5) dalam hal daerah telah terdapat dokter kewenangan perawat tidak berlaku. Pada Undang-Undang Republik Indonesia Nomor 38 Tahun 2014 tentang keperawatan bagian kedua adalah Tugas dan Wewenang Pasal 29 sebagai berikut :

1) Dalam menyelanggarakan Praktik Keperawatan, Perawat bertugas sebagai
a. Pemberi Asuhan Keperawatan
b. Penyuluh dan konselor bagi klien;
c. Pengelola Pelayanan Keperawatan;
d. Peneliti Keperawatan; 
e. Pelaksana tugas berdasarkan pelimpahan wewenang; dan/atau

f. Pelaksana tugas dalam keadaan keterbatasan tertentu.

2) Tugas sebagaimana dimaksud pada ayat (1) dapat dilaksanakan secara bersama ataupun sendiri-sendiri.

3) Pelaksana tugas Perawat sebagaimana dimaksud pada ayat (1) harus dilaksanakan secara bertanggung jawab dan akuntabel.

Indonesia juga telah memiliki UU khusus tentang keperawatan, yakni Undang-Undang Republik Indonesia Nomor 38 Tahun 2014 tentang keperawatan. Di dalam UU tersebut tersedia keterangan mengenai jenis perawat, pendidikan tinggi keperawatan, registrasi/izin praktik keperawatan, hak dan kewajiban perawat/klien, praktik keperawatan, organisasi profesi keperawatan, kolegium keperawatan, konsil keperawatan, sanksi administratif bagi perawat, serta pengembangan, pembinaan, dan pengawasan keperawatan. Lahirnya UU Keperawatan ini didasarkan pada asas bahwa penyelenggaraan pembangunan kesehatan harus diwujudkan melalui penyelenggaraan pelayanan kesehatan, termasuk pelayanan keperawatan. Penyelenggaraan pelayanan keperawatan ini harus dilakukan bertanggung jawab, akuntabel, bermutu, aman dan terjangkau oleh perawat yang memiliki kompetensi, kewenangan, etik, dan moral tinggi. Oleh karena itu, segala sesuatu mengenai keperawatan perlu diatur secara komprehensif dalam peraturan perundang-undangan guna memberikan perlindungan dan kepastian hukum kepada perawat dan masyarakat. ${ }^{27}$ Undang-Undang Republik Indonesia Nomor 38 Tahun 2014 Tentang Keperawatan Pasal 32 ayat Pelaksanaan tugas berdasarkan pelimpahan wewenang sebagaimana dimaksud dalam Pasal 29 ayat (1) huruf e hanya dapat diberikan secara tertulis oleh tenaga medis kepada perawat untuk melakukan sesuatu tindakan medis dan evaluasi pelaksanaannya. Ayat pelimpahan wewenang sebagaimana dimaksud pada pada ayat (1) dapat dilakukan secara delegatif atau mandat. Ayat (3) pelimpahan wewenang secara delegatif untuk melakukan sesuatu tindakan medis diberikan oleh tenaga medis kepada perawat dengan disertai pelimpahan tanggung jawab.Ayat (4) pelimpahan wewenang secara delegatif

\footnotetext{
${ }^{27}$ Ni Ketut Mendri \& Agus Sarwo P, Etika dan Hukum Keperawatan, Pustaka Baru, Yogyakarta, 2017, Hlm. 33
} 
sebagaimana dimaksud pada ayat (3) hanya dapat diberikan kepada perawat profesi atau perawat vokasi terlatih yang memiliki kompetensi yang diperlukan. Ayat (5) pelimpahan wewenang secara mandat diberikan oleh tenaga medis kepada perawat untuk melakukan sesuatu tindakan medis di bawah pengawasan.Ayat (6) Tanggung jawab atas tindakan medis pada pelimpahan wewenang mandat sebagaimana dimaksud pada ayat (5) berada pada pemberi pelimpahan wewenang. Pasal (7) dalam melaksanakan tugas berdasarkan pelimpahan wewenang sebagaimana dimaksud pada ayat (1), perawat berwenang :

a. Melakukan tindakan medis yang sesuai dengan kompetensinya atas pelimpahan wewenang delegatif tenaga medis;

b. Melakukan tindakan medis di bawah pengawasan atas pelimpahan wewenang mandat; dan

c. Memberikan pelayanan kesehatan sesuai dengan program pemerintah. ${ }^{28}$ Dalam penjelasan Undang-Undang Republik Indonesia No. 38 Tahun 2014 Pasal 32 Ayat (4) dijelaskan bahwa

\footnotetext{
${ }^{28}$ Undang- Undang Keperawatan RI Nomor 38 Tahun 2014 Tentang Keperawatan
}

tindakan medis yang dapat dilimpahkan secara delegatif, antara lain menyuntik, memasang infus, dan memberikan imunisasi dasar sesuai dengan program pemerintah. Pasal 32 ayat (5) pelimpahan wewenang secara mandat diberikan oleh tenaga medis (dokter) kepada perawat untuk melakukan sesuatu tindakan medis dibawah pengawasan, tanggung jawab berada pada pemberi mandat. Tindakan medis yang dapat dilimpahkan secara mandat, antara lain adalah pemberian terapi parenteral dan penjahitan luka.

Berdasarkan Pasal 23 Permenkes No.2052/Menkes/Per/X/2011 Tentang Izin Praktik dan Pelaksanaan Praktik Kedokteran Pasal 23 ayat (1) Dokter atau dokter gigi dapat memberikan pelimpahan suatu tindakan kedokteran atau kedokteran gigi kepada perawat, bidan atau tenaga kesehatan tertentu lainnya secara tertulis dalam melaksanakan tindakan kedokteran atau kedokteran gigi. ${ }^{29}$ Dalam kondisi keterbatasan tenaga dokter dan tugas pokoknya adalah pemberian pelayanan kesehatan perorangan terutama dalam pengobatan, perawat sering menggantikan posisi dokter memeriksa dan mengobati.Penelitian Depkes dan UI pada

\footnotetext{
${ }^{29}$ Permenkes No. 2052/Menkes/Per/X/2011 Pasal 23 Tentang Izin Praktik dan Pelaksanaan Praktik Kedokteran
} 
tahun 2005 menunjukkan masih banyaknya penanganan pengobatan $(97 \%) .{ }^{30}$ Sesuai dengan tujuan dibuatnya peraturan atau hukum untuk ketertiban dan perlindungan kepada masyarakat dan warga khususnya dalam tindakan pemberian injeksi streptomisin. Alternatif solusi dari kondisi ini agara tenaga dokter ditambah sesuai kebutuhan dengan pendistribusian yang merata, dan jelas reward dan punishment.

Puskesmas merupakan ujung tombak penyelenggaraan upaya kesehatan masyarakat (UKM) maupun upaya kesehatan perorangan (UKP) di strata pelayanan kesehatan, dan merupakan unit pelaksana teknis dinas kesehatan kabupaten atau kota. Upaya kesehatan yang diselenggarakan oleh puskesmas meliputi upaya kesehatan wajib yaitu (promosi kesehatan, kesehatan lingkungan, KIA/Kesehatan Ibu dan Anak dan Keluarga Berencana (KB), Pemberantasan Penyakit Menular (P2M), Gizi dan Pengobatan). Dan Upaya kesehatan pengembangan. Kinerja puskesmas, sebagai pelayanpelayanan kesehatan dasar yang paling dekat dengan masyarakat sangat menentukan kinerja

\footnotetext{
${ }^{30}$ RENSTRA Kementerian Kesehatan Tahun 2009
}

kabupaten/kota untuk mewujudkan masyarakat sehat diwilayahnya. ${ }^{31}$

Saat ini permasalahan kesehatan yang dihadapi cukup komplek, upaya kesehatan belum menjangkau seluruh masyarakat meskipun puskesmas telah ada di setiap kecamatan dan ditunjang dengan puskesmas pembantu. Hal ini ditunjukkan dengan angka kematian bayi 35 per1000 kelahiran hidup (SDKI 2002-2003) angka kematian ibu 307 per100.000 kelahiran hidup. Masalah kesehatan lainnya adalah munculnya penyakit (emerging desease) seperti HIV/AIDS, SARS, cikungunya dan meningkatnya kembali penyakit- penyakit menular (re-emerging deseases) seperti TBC, malaria serta penyakit yang dapat dicegah dengan imunisasi dan penyakit degeneratif serat penyakit jantung dan pembuluh darah juga terjadi peningkatan. ${ }^{32}$ Pengobatan yang diberikan oleh perawat biasanya terdiri dari dua tindakan teknis, yakni injeksi/suntikan dan pemberian obat untuk diminum. Sekitar 80 sampai 90 persen dari kasus yang ditangani perawat menerima suntikan Intramuscular $(I M)$ dari satu jenis obat

\footnotetext{
${ }^{31}$ Kepmenkes RI Nomor 128 Tahun 2004 Tentang Kebijakan Dasar Puskesmas.

${ }^{32}$ Kepmenkes RI Nomor 279/Menkes/SK/IV/2006

Tentang Pedoman Penyelanggaraan Upaya Keperawatan Kesehatan Masyarakat di Puskesmas
} 
atau jenis obat yang lain. ${ }^{33}$ Sesuai dengan Undang-Undang Keperawatan Nomor 38 Tahun 2014 tentang Tugas dan Wewenang perawat Pasal 29 ayat (1) huruf a Perawat pemberi asuhan keperawatan dan ayat (1) huruf e Perawat Pelaksana tugas berdasarkan pelimpahan wewenang, Pasal 32 ayat (1) pelaksanaan tugas berdasarkan pelimpahan wewenang sebagaimana dimaksud dalam Pasal 29 ayat (1) huruf e pelimpahan wewenang hanya dapat diberikan secara tertulis oleh tenaga medis kepada perawat untuk melakukan sesuatu tindakan medis dan melakukan evaluasi pelaksanaannya. Berdasarkan data penelitian yang penulis dapatkan di Puskesmas Pasirkaliki bahwa pengobatan injeksi streptomisin dilakukan oleh perawat tanpa ada surat pelimpahan wewenang. Tindakan perawat pada pasien TB Paru seharusnya adalah intervensi keperawatan yang dapat dilakukan untuk mengatasi masalah yang dihadapi oleh pasien TB Paru adalah sebagai berikut: 1) Peningkatan bersihkan jalan nafas, sekresi yang sangat banyak dapat menyumbat jalan nafas pada pasien TB Paru dan mengganggu pertukaran gas. Meningkatkan masukan- masukan cairan

\footnotetext{
${ }^{33}$ Rosalia Sciortino, Perawat Puskesmas di Antara Pengobatan dan Perawatan, Gadjah Mada University press, 2008, Hlm. 227
}

memberikan hidrasi sistemik dan berfungsi sebagai ekspektoran yang efektif. Pasien diberitahu posisi-posisi yang dapat memudahkan drainase secret. Humidifier atau face mask dengan kelembaban tinggi dapat membantu dalam mengencerkan sekresi, 2) Mendukung kepatuhan terhadap pengobatan, pasien harus memahami bahwa TB Paru adalah penyakit menular sehingga meminum obat secara tepat dan teratur adalah cara efektif dalam pencegahan penularan. Pengertian tentang obatan-obatan, jadwal dan efek samping harus dujelaskan pada pasien. Selain itu, penjelasan tentang pentingnya tindakan higienis, termasuk oral hygiene, menutup mulut ketika bersin serta mencuci tangan juga harus diberitahu kepada pasien, 3) Meningkatkan aktifitas dan nutrisi yang adekuat, pasien TB sering merasa sangat lemah karena penyakit kronis dan juga gangguan pemenuhan nutrisi. Pasien dapat diatur jadwal aktifitas secara progresif dengan berfokus pada peningkatan toleransi aktifitas dan kekuatan otot. Anoreksia, penurunan berat badan dan malnutrisi biasa terjadi pada pasien TB Paru. Keinginan untuk makan dapat terganggu oleh keletihan akibat batuk berat, pembentukan sputum, nyeri dada 
atau kelemahan. Pemberian nutrisi dalam porsi kecil tapi sering dapat di jadwalkan. Suplemen nutrisi cair dapat membantu memenuhi kebutuhan kalori dasar, 4) Penyuluhan pasien dan pertimbangan perawatan dirumah, perawat mempunyai peran yang sangat penting dalam merawat pasien TB Paru dan keluarganya, termasuk mengkaji kemampuan pasien untuk melanjutkan terapi di rumah. Perawat mengkaji pasien terhadap reaksi obat yang merugikan dan ikut serta dalam mensurvei rumah dan lingkungan kerja pasien untuk mengidentifikasi individu lain yang mugkin telah kontak dengan pasien selama tahap infeksius. ${ }^{34}$

Analisis hukum terhadap kewenangan perawat dalam melaksanakan pelayanan keperawatan, diatur dalam Undang-Undang Kesehatan Nomor 36 Tahun 2009, Undang-Undang Nomor 38 Tahun 2014 Tentang Keperawatan, Permenkes Nomor 17 Tahun 2013 Tentang izin dan penyelenggaraan praktik perawat, kewenangan utama perawat adalah melaksanakan asuhan keperawatan, ditinjau dari kasus hukum yang terjadi tahun 2018 perawat di Puskesmas Pasirkaliki melaksanakan pelayanan

\footnotetext{
${ }^{34}$ Devi Darliana, Jurnal Bagian Keilmuan Keperawatan Medikal Bedah, PSIK-FK Universitas Syiah Kuala, 2017, Hlm. 30
}

kesehatan diluar kewenangan tanpa disertai dengan pelimpahan wewenang secara tertulis oleh dokter dengan melakukan tindakan injeksi streptomisin. Kasus yang terjadi atas tindakan injeksi dikerjakan oleh perawat tidak sesuai dengan kewenangan serta tanpa ada pendelegasian dan mandat secara tertulis dari dokter, kasus yang terjadi diatas menjadi tanggung jawab perawat yang melakukan pelayanan kesehatan, perawat memiliki tanggung jawab dan tanggung gugat hukum terhadap tindakan yang dilakukannya, tetapi apabila tindakan tersebut atas perintah dokter, tanggung jawab dan tanggung gugat berada pada dokter.

\section{B. PEMBAHASAN}

Implementasi Kewenangan Perawat dalam Memberikan Tindakan Injeksi Streptimisin Pasien TB Paru Puskemas Pasirkaliki Menurut Undang-Undang Nomor 38 Tahun 2014 Tentang Keperawatan Dihubungkan Dengan Peraturan Menteri Kesehatan Nomor 39 Tahun 2016 Tentang Pedoman Penyelenggaraan Program Indonesia Sehat Dengan Pendekatan Keluarga 
Jumlah Puskesmas di Kota Bandung adalah 30 Puskesmas yaitu terdiri Puskesmas Sukarasa, Puskesmas Sukajadi, Puskesmas Pasirkaliki, Puskesmas Garuda, Puskesmas Ciumbuleuit, Puskesmas Puter, Puskesmas Salam, Puskesmas Tamblong, Puskesmas Neglasari, Puskesmas Padasuka, Puskesmas Babakan Sari, Puskesmas Ibrahim Adjie, Puskesmas Talagabodas, Puskesmas Pasundan, Puskesmas Pagarsing, Puskesmas Citarip, Puskesmas Kopo, Puskesmas Caringin, Puskesmas Cibuntu, Puskesmas Griya Antapani, Puskesmas Sindangjaya, Puskesmas Arcamanik, Puskesmas Ujungberung Indah, Puskesmas Cinambo, Puskesmas Cibiru, Puskesmas Panghegar, Puskesmas Riung Bandung, Pukesmas Cipamokolan, Puskesmas Margahayu Raya, Puskesmas Kujangsari.

Secara umum upaya kesehatan terdiri dari atas dua unsur utama, yaitu upaya kesehatan masyarakat dan upaya kesehatan perorangan.Upaya kesehatan masyarakat adalah setiap kegiatan yang dilakukan oleh pemerintah dan atau masyarakat serta swasta, untuk memelihara dan meningkatkan kesehatan serta mencegah dan menyembuhkan penyakit serta memulihkan kesehatan perorangan. Berbagai upaya pemerintah telah dilakukan untuk meningkatkan derajat kesehatan masyarakat, antara lain melalui upaya kesehatan dasar, upaya kesehatan rujukan, perbaikan gizi masyarakat serta upaya kesehatan rujukan, perbaikan gizi masyarakat serta upaya kesehatan olahraga, upaya perawatan kesehatan masyarakat, upaya kesehatan gigi dan mulut, upaya kesehatan mata, upaya kesehatan jiwa, dan upaya pembinaan pengobatan tradisional.

Selain kewenangan, kompetensi, dalam memberikan pelayanan kepada masyarakat seorang perawat juga harus bekerja sesuai dengan fungsi (seperangkat tugas, tanggung jawab dan kegiatan yang diharapkan di laksanakan sesorang sesuai dengan peran atau posisinya) dari perawat meliputi tiga fungsi yaitu fungsi independen, dalam fungsi ini tindakan perawat tidak memerlukan perintah dokter, tindakan perawat bersifat mandiri, berdasarkan pada ilmu dan kiat keperawatan. Oleh karena itu perawat bertanggung jawab terhadap akibat yang timbul dari tindakan yang diambil, fungsi yang lain fungsi interdependen, tindakan perawat berdasar pada kerjasama dengan tim perawatan/tim kesehatan, lebih lebih lanjut fungsi dependen, dalam fungsi ini 
perawat bertindak membantu dokter bertanggung jawab atas tindakan yang dalam memberikan pelayanan medik, dilakukan oleh penerima mandat perawat membantu dokter memberikan (mandataris) yaitu perawat, dokter sebagai pelayanan pengobatan dan tindakan khusus yang menjadi wewenang dokter dan seharusnya dilakukan oleh dokter seperti pemasangan infus, pemberian obat, melakukan injeksi. Oleh karena itu setiap kegagalan tindakan medis menjadi tanggung jawab dokter.Setiap tindakan perawat yang berdasarkan perintah dokter, dengan menghormati hak pasien tidak termasuk tanggung jawab perawat.Apabila dilihat dari tiga fungsi perawat yaitu fungsi independen, fungsi interdependen dan fungsi dependen lebih banyak dikerjakan oleh perawat dan sangat dominan seolah-olah perawat bekerja atas perintah dokter selama di institusi kemudian dilanjutkan di luar institusi perawat lebih senang mengerjakan tugas dependen yang seharusnya fungsi independen dan interdependen menjadi tanggung jawab seorang perawat yang merupakan fungsi utama yaitu asuhan keperawatan.

Seorang dokter, sebagai organ pemerintah mengizinkan kewenangannya dijalankan oleh organ lain yaitu perawat atas nama dokter. Dalam hal ini dokter sebagai pemberi mandat (mandans) pemberi mandat tetap bertanggung jawab untuk mengambil sendiri kewenangan tersebut apabila dikehendakinya, tanggung jawab akhir keputusan yang diambil oleh perawat tetap berada pada dokter. Pada mandat tidak dibicarakan penyerahan wewenang tidak pula pelimpahan wewenang yang ada hanyalah hubungan internal. Dalam kajian Hukum Administrasi Negara mengenai sumber dari cara memperoleh wewenang organ pemerintah harus diketahui karena berkenaan dengan tanggung jawab hukum. Prinsip dalam Negara hukum (Tidak ada kewenangan tanpa pertanggungjawaban).

Menurut penulis pasca pengesahan Undang-Undang Republik Indonesia Nomor 38 Tahun 2014 Tentang Keperawatan.Pelimpahan wewenang harus dilakukan secara delegatif atau mandat disertai dengan pelimpahan wewenang secara tertulis kepada perawat profesi atau vokasi yang sudah terlatih untuk melakukan tindakan medis dibawah pengawasan. Hal ini sesuai juga dengan Permenkes No.2052/Menkes/Per/X/2011 Tentang Izin Praktik dan Pelaksanaan Praktik Kedokteran Pasal 23 ayat (1) 
Dokter atau dokter gigi dapat memberikan pelimpahan suatu tindakan kedokteran atau kedokteran gigi kepada perawat, bidan atau tenaga kesehatan tertentu lainnya secara tertulis dalam melaksanakan tindakan kedokteran atau kedokteran gigi.

Sedangkan berdasarkan hasil penelitian yang dilakukan di Puskesmas Pasirkaliki mulai tanggal 28 September 2017 s/d 28 Maret 2018 didapatkan data hasil wawancara dari 6 perawat dan 2 dokter mengatakan tidak adanya pelimpahan wewenang secara tertulis melainkan pelimpahan kewenangan hanya dilakukan secara lisan. Menurut penulis salah satu syarat tindakan pelimpahan wewenang injeksi streptomisin yang dilakukan oleh perawat harus didasari dengan pelimpahan wewenang secara tertulis agar perawat memiliki kekuatan hukum yang kuat dan mengikat.

\section{PENUTUP}

\section{Simpulan}

1. Pengaturan kewenangan perawat yang memberikan tindakan injeksi streptomisin pasien TB Paru menurut Undang-Undang Nomor 38 Tahun 2014 Tentang Keperawatan adalah merupakan pelimpahan wewenang berupa delegasi secara tertulis untuk melakukan sesuatu tindakan medis kepada perawat disertai pelimpahan tanggung jawab dan tanggung gugat yang hanya dapat diberikan kepada perawat profesi atau vokasi terlatih yang memiliki kompetensi.

2. Implementasi kewenangan perawat dalam memberikan tindakan injeksi streptomisin pasien TB Paru di Puskemas Pasirkaliki menurut Undang-Undang Nomor 38 Tahun 2014 Tentang Keperawatan Dihubungkan Dengan Peraturan Menteri Kesehatan Nomor 39 Tahun 2016 Tentang Pedoman Penyelenggaraan Program Indonesia Sehat Dengan Pendekatan Keluarga belum dilaksanakan secara tertulis. Setiap perawat yang melakukan tindakan injeksi streptomisin di Pukesmas Pasirkaliki belum pernah menerima surat pelimpahan wewenang dari dokter secara tertulis melainkan hanya sebatas lisan.

\section{Saran}

1. Bagi dokter di Puskesmas Pasirkaliki Kota Bandung ketentuan mengenai pelimpahan wewenang secara tertulis berupa delegasi ditempat kerja perlu dibuat dengan merujuk pada 
Pasal 23 ayat 1 Peraturan Menteri

Kesehatan

Nomor

2052/Menkes/Per/X/2011

Tentang Izin Praktik dan

Pelaksanaan Praktik Kedokteran.

2. Bagi perawat sebagai pelaksana tugas yang melaksanakan tindakan injeksi streptomisin berdasarkan pelimpahan wewenang dari dokter, hendaknya meminta surat pendelegasian sesuai dengan Pasal 29 ayat (1) huruf e dan Pasal 32 ayat (1) UndangUndang Nomor 38 Tahun 2014 Tentang Keperawatan.

3. Bagi Puskesmas hendaknya membuat Standar Operasional Prosedur (SOP) berupa surat pelimpahan wewenang secara tertulis dari dokter kepada perawat dalam memberikan tindakan injeksi streptomisin diluar wewenang praktik keparawatan pada pasien TB Paru kategori 2.

\section{DAFTAR PUSTAKA}

\section{Buku- Buku}

A'an Efendi dan Freddy Poernomo, Hukum Administrasi, Sinar Grafika, Jakarta, 2017

As'ad Sungguh, Kode Etik Profesi Tentang Kesehatan.

Kedokteran, Psikologi, Kebidanan, Keperawatan, Apoteker, dan Rumah Sakit, Sinar Grafika, Jakarta, 2014

A. Aziz Halimul Hidayat, Pengantar Konsep Dasar Keperawatan, Cetakan Ketiga, Salemba Medika, Jakarta, 2008

B. Erb, Kozier dan Oliveri. R, Fundamental of Nursing Concept, Process and Practice, ${ }^{4 t h}$ Ed.,Redwood City: Addison-Wesley, 1991. C. Lilis, Taylor dan Lemone P. Fundamental of Nursing: The Art and Science of Nursing Care. $2^{\text {nd }}$ Ed. Philadelphia: Lippincott. Dalam Jurnal Kedokteran \& Kesehatan, JKK, Th. 40 No. 3 Juli 2008. ISSN 0-853-1773

Bishop, Anne, Nursing Ethics: Holistic Caring Practice, ${ }^{2 n d} E d$; Alih Bahasa: Helwiyah Ropi, EGC, Jakarta, 2006 
Makmur Jaya, Kewenangan Perawat Dalam Memberikan Tindakan Injeksi Streptomisin Di Puskesmas...

Budiono, Sumirah Budi Pertami, Konsep Dasar Keperawatan, Bumi Medika, Jakarta, 2016

Budiman, Buku Ajar Isu Tataran Kesehatan Masyarakat, PT. Refika

Aditama

Bandung,2015

Buku Pedoman Penulisan Tesis dan

Disertasi, Program

Pascasarjana Universitas Islam

Bandung, 2016

Cecep Tri wibowo, Hukum Keperawatan Panduan Hukum dan Etika Bagi Perawat, Pustaka Book Publisher, Yogyakarta, 2010

Daryanto, Kamus Bahasa Indonesia Lengkap, Apollo Lestari, Surabaya, 1997

Deden Dermawan, Pengantar Keperawatan Profesional, Gosyen Publishing, Yogyakarta, 2013

Departemen Kesehatan Republik Indonesia, Pharmaceutical Care Untuk Penyakit Tuberkulosis, Dirjen Bina Farmasi Komunitas dan Klinik , 2005
Gaffar (1997) dalam Kementerian Kesehatan Republik Indonesia, Modul Bahan Ajar Cetak Keperawatan, Konsep Dasar Keperawatan, Pusdik SDM Kesehatan, Jakarta, 2016

Harif Fadhillah dkk, PPNI Pedoman Praktik Keperawatan Mandiri, Tim Penyusun DPP PPNI, Jakarta 2017

Hendrik, Etika dan Hukum Kesehatan, Jakarta, EGC, 2013

H.M.Saiful Rahman, Pembangunan dan otonomi Daerah, Realisasi Kabinet Gotong Royong, Yayasan Pancur Siwah, Jakarta, 2004

Ikatan Dokter Indonesia, Panduan Praktik Klinis Bagi Dokter di Fasilitas Pelayanan Kesehatan Tingkat Pertama, Jakarta, 2014

Kementerian Kesehatan Republik Indonesia, Pedoman Umum Program Indonesia Sehat Dengan Pendekatan Keluarga, Jakarta, 2016 
Makmur Jaya, Kewenangan Perawat Dalam Memberikan Tindakan Injeksi Streptomisin Di Puskesmas...

Kementerian Kesehatan Republik

Indonesia, Modul Bahan Ajar

Cetak Keperawatan, Konsep

Dasar Keperawatan, Pusdik

SDM Kesehatan, Jakarta,

2016

Kementerian Kesehatan Republik

Indonesia, Pedoman Umum

Program Indonesia Sehat

Dengan Pendekatan

Keluarga, Jakarta, 2016

KemenkesRI, Pedoman Nasional

Pengendalian Tuberkulosis,

Direktorat Jenderal

Pengendalian Penyakit dan

Penyehatan Lingkungan, 2011

KepalaBagian Tata Usaha Pusat

Kesehatan Masyarakat

(PUSKESMAS) Pasirkaliki

Kota Bandung, 2018

La Ode Jumadi Gaffar, Hasil

Lokakarya Nasional

Keperawatan tahun 1983,

Pengantar Keperawatan

Profesional, Jakarta: EGC, 1999

Masruroh Hasyim dkk, Buku

Pedoman Keperawatan dari

Etika sampai Kamus
Keperawatan, Indoliterasi, Yogyakarta, 2014

Masteman (1970) dan Poerwoto P (1997) dalam A. Aziz Halimul

Hidayat, Pengantar Konsep

Dasar Keperawatan, Cetakan

Ketiga, Salemba Medika,

Jakarta, 2008

Modul Pelatihan Keluarga Sehat, Pusat Pelatihan SDM

Kesehatan Badan PPSDM

Kesehatan Kementerian

Kesehatan Tahun 2017

Neni Sri Imaniyati \& Panji Adam, Pengantar Hukum Indonesia, Sinar Grafika, Jakarta, 2018

Ni Ketut Mendri \& Agus Sarwo P, Etika dan Hukum Keperawatan, Pustaka Baru, Yogyakarta, 2017

Nila Ismani, Hj, Etika Keperawatan, Widya Medika, Jakarta, 2006.

Nomensen Sinamo, Hukum Administrasi Negara. Jala Permata Aksara, Jakarta, 2010 Nur Basuki Minarno, Penyalahgunaan Wewenang dalam Pengelolaan Keuangan, Laksbang

Mediatama, Surabaya, 2010 
Makmur Jaya, Kewenangan Perawat Dalam Memberikan Tindakan Injeksi Streptomisin Di Puskesmas...

Nursalam, Manajemen Keperawatan: Aplikasi Dalam Keperawatan Profesional, Salemba Medika, Jakarta, 2002,

Nursalam, Managemen Keperawatan Aplikasi dalam Praktik Keperawatan Profesional, Salemba Medika, Jakarta, 2016

Pengertian Wewenang Menurut H.D. Staud dalam Juniarso Ridwan dan Ahmad Sodik Sudrajat, Hukum Administrasi Negara dan Kebijakan Pelayanan Publik, PT. Nuansa, Bandung, 2009

Potter, Patricia A, Buku Ajar Fundamental Keperawata : Konsep, Proses, dan Praktik.

Ed. 4, EGC, Jakarta, 2005

Prajudi Atmosudirjo, Hukum Administrasi Negara, Ghalia Indonesia, Jakarta, 1994

Ridwan HR, Hukum Administrasi Negara, PT. Raja Grapindo Persada, Jakarta, 2006

Riky, Proses Pemurnian Streptomisin

Dari Produk Fermentasi. Institut Teknologi Bandung (ITB), 2015
Roeslan Saleh,Penjabaran Pancasila dan UUD 1945 Dalam Perundang-undangan, Jakarta: Bina Aksara, 1979

Rosalia Sciortino, Perawat Puskesmas di Antara Pengobatan dan Perawatan, Gadjah Mada University press, 2008

R. Subekti dan Tjitrosudibio, Kitab Undang-undang Hukum Perdata, PT. Pradnya Paramitra, Jakarta, 2003

Soerjono Soekanto, Pengantar Penelitian Hukum, Jakarta, Universitas Indonesia, 1984

Soerjonodan Sri Mamudji, Penelitian Hukum Normatif, Suatu Tinjauan Singkat, Jakarta :Rajawali Press, 1995

Sofyan dan Harry, Konsumen dan Pasien, Liberty, Yogyakarta, 2008

Sri Praptianingsih, Kedudukan Hukum Perawat Dalam Upaya Pelayanan Kesehatan di Rumah Sakit, Raja Grafindo Persada, Jakarta, 2006

Sri Siswati, Etika \& Hukum Kesehatan Dalam Perspektif 
Undang-Undang Kesehatan,

PT. Raja Grafindo Persada, Jakarta, 2015

St. Remy Sjahdeini dkk., Naskah Akademis Dalam Peraturan Perundang-undangan tentang Perbuatan Melawan Hukum, Jakarta: Badan Pembinaan Hukum Nasional. Departemen Kehakiman RI, 1993/1994

Ta'adi, Hukum Kesehatan, Sanksi \& Motivasi bagi Perawat, EGC, Jakarta, 2012

Toto Tohir Suriaatmaja, Hukum Keagenan Dalam Berbagai Sistem Hukum (Kajian Hukum Awal), CV. Insan Mandiri, Bandung, 2011

Triloka H. Putrid dan Achmad Fanani, Etika Profesi Keperawatan, Citra Pustaka, Yogyakarta, 2011

Yuslim, Hukum Acara Peradilan Tata Usaha Negara, Jakarta: Sinar Grafika, 2016

\section{Peraturan Perundang - Undangan}

Undang- Undang Republik Indonesia Nomor 36 Tahun 2009 Tentang Kesehatan
Undang-Undang Republik Indonesia

Nomor 36 Tahun 2014

Tentang Tenaga Kesehatan

Undang- Undang Republik Indonesia Nomor $38 \quad$ Tahun 2014Tentang Keperawatan

Undang-Undang Republik Indonesia Nomor 29 Tahun 2004

Tentang Praktik Kedokteran

PP Nomor 32 Tahun 1996 Tentang Kesehatan

Permenkes

No.2052/Menkes/Per/X/2011

Pasal 23 Tentang Izin Praktik dan Pelaksanaan Praktik Kedokteran

Peraturan Menteri Kesehatan Republik Indonesia Nomor 17 Tahun 2013 Perubahan atas Permenkes Nomor HK.02.02/MENKES/148/201 0 Tentang Izin dan Penyelenggaraan Praktik Perawat.

Keputusan Menteri Kesehatan Nomor 1239/MENKES/SK/XI/2001 Tentang Registrasi dan Praktik Perawat (revisi SK No.

647/MENKES/SK/IV/2000 
Makmur Jaya, Kewenangan Perawat Dalam Memberikan Tindakan Injeksi Streptomisin Di Puskesmas...

Peraturan Menteri Kesehatan

Republik Indonesia Nomor 40

Tahun $2017 \quad$ tentang

Pengembangan Jenjang Karir

Profesional Perawat Klinis.

Lampiran Keputusan Menteri Tenaga

Kerja dan Transmigrasi

Republik Indonesia Nomor:

KEP/148/MEN/III/2007

Tentang Penetapan Standar

Kompetensi Kerja Nasional

Indonesia Sektor Jasa

Kesehatan Bidang Keahlian

Keperawatan

Kepmenkes Republik Indonesia

Nomor279/MENKES/SK/IV/

2006 Tentang Pedoman

Penyelanggaraan Kesehatan

Masyarakat di Puskesmas

Permenkes Republik Indonesia

Nomor 148 Tahun 2010

Tentang Izin Praktik Perawat

Permenkes Republik Indonesia

Nomor 971/2009 Tentang

Standar Kompetensi Jabatan

Struktural Kemenkes

Permenkes Republik Indonesia

Nomor 75 Tahun 2014 Tentang

Puskesmas
Permenkes Republik Indonesia

Nomor 129 Tahun 2004

Tentang Pedoman Pelayanan

Kesehatan di Puskesmas

Permenkes Republik Indonesia

Nomor 67 Tahun 2016

Tentang Penanggulangan

Tuberkulosis.

Permenkes Republik Indonesia

Nomor 290/Menkes/Per/2008

Tentang Persetujuan Tindakan

Medis.

Peraturan Menteri Kesehatan Republik Indonesia Nomor 161/MENKES/PER/I/2010

Tentang Registrasi Tenaga

Kesehatan

Permenkes RI No. 40 Tahun 2017

Tentang Pengembangan

Jenjang Karir Profesional

Perawat Klinis

\section{Jurnal}

Devi Darliana, Bagian Keilmuan Keperawatan Medikal Bedah, Surgery and Medical Nursing Departement Faculty of Medicine, PSIK-FK Universitas Syiah Kuala, 2017 Etty Nurul Afidah \& Madya Sulisno, jurnal.unimus.ac.id/index.php/ 
JMK/article. Gambaran

Pelaksanaan Peran Advokat

Perawat di Rumah Sakit

Negeri di Kabupaten

Semarang, 2013

Harif Fadilah, dalam seminar One Step dengan tema "Optimalisasi Peran dan Fungsi Mahasiswa Keperawatan melalui Character Building of Caring" di Graha Sanusi Hardjadinata kampus Unpad, Jln. Dipati Ukur No. 35 Bandung, Sabtu (21/05). Acara ini digelar oleh Fakultas Keperawatan (Fkep) Unpad dalam rangka Dies Natalis Fkep Unpad ke-17.

Reny Suryanti, pelimpahan wewenang Dokter kepada Perawat Dalam tindakan Medis di Ruang Rawat inap RSUD Kabupaten Badung sebagai upaya pencegahan terjadinya kelalaian, Tesis, Universitas Gadja Mada, 2011 Kementerian Kesehatan RI, Situasi Tenaga Keperawatan Indonesia, Jakarta, Infodatin (ISSN 2442-7659), Pusat Data dan Informasi Kementerian Kesehatan RI, 2017.

Suster Calista Roy adalah seorang suster dari Saint Joseph of Carondelet. Roy dilahirkan pada tanggal 14 oktober 1939 di Los Angeles California. Roy menerima Bachelor of Art Nursing pada tahun 1963 dari Mount Saint Marys College dan Magister Saint in Pediatric Nursing pada tahun 1966 di University of California Los Angeles.

Berpikir holistik berarti berpikir secara menyeluruh dengan mempertimbangkan segala aspek yang mungkin mempengaruhi tingkah laku manusia atau suatu kejadian.

(https://www.kompasiana.com/novieo cktavia/psycholostoryberpikirholistik_54f984d6a33311a971 8b480c). Diunduh tanggal 25 Januari 2018, jam 15.55 WIB. PPNI,Standar Kompetensi Perawat Indonesia, Edisi IV,Jakarta, 2013 
Makmur Jaya, Kewenangan Perawat Dalam Memberikan Tindakan Injeksi Streptomisin Di Puskesmas...

DPD PPNI, Kode Etik Keperawatan di Indonesia, PPNI, Jakarta, 1995

Jurnal Kedokteran \& Kesehatan. Publikasi Ilmiah Fakultas Kedokteran Universitas Sriwijaya. Praktik Keperawatan Profesional. JKK, Th. 40 No. 3 Juli 2008. ISSN 0-853-1773

Data didapatkan dari Pelatihan Asesor

Klinik Keperawatan oleh Himpunan Perawat Manajer Indonesia

Rencana Pembangunan Jangka Panjang Menengah Nasional ,Sinar Grafika, 2004

Amperaningsih, Jurnal Kesehatan Kinerja Perawat Dalam Pelaksanaan Perkesmas, Bandar Lampung, 2012

Devi Darliana, Manajemen Pasien Tuberculosis Paru, PSIK-FK Universitas Syiah Kuala, 2017 Gunawan Aineka, Tanggung Jawab Perawat Terhadap Pasien Dalam Pelimpahan

Kewenangan Dokter Kepada

Perawat, Riau

Kementerian Kesehatan RI, Situasi Tenaga

Keperawatan
Indonesia, Jakarta, Infodatin (ISSN 2442-7659), Pusat Data dan Informasi Kementerian Kesehatan RI, 2017

Kementerian Kesehatan RI, Situasi Tenaga Keperawatan Indonesia, Infodatin (ISSN 2442-7659), Pusat Data dan Informasi Kementerian Kesehatan RI, Jakarta, 2017

\section{Internet}

https://shantidk.wordpress.com/2013/ 08/29/pelimpahan-wewenangdalam-rancangan-undangundang-tentang-keperawatan/

http://www.negarahukum.com/hukum /pengertian-

kewenangan.html.Diunduh tanggal 17 Juni 2017, jam 01.13 WIB.

http://stikesayani.ac.id/publikasi/ejournal/filesx/2009/200908/20 0908-002.pdf

http://www.pikiranrakyat.com/bandungraya/2017/10/16/diskriminasipenderita-tb-masih-terjadi411653 
Makmur Jaya, Kewenangan Perawat Dalam Memberikan Tindakan Injeksi Streptomisin Di Puskesmas... 